\title{
Chrysocoma ciliata L. (Asteraceae) in the Lesotho Highlands: An anthropogenically introduced invasive
} or a niche coloniser?

Jennifer M. Fitchett*1,2, Marion K. Bamford ${ }^{2}$, Anson W. Mackay ${ }^{3}$ and Stefan W. Grab ${ }^{1}$

${ }^{1}$ School of Geography, Archaeology and Environmental Studies, University of the Witwatersrand, Private Bag 3, Johannesburg, 2050, South Africa.

${ }^{2}$ Evolutionary Studies Institute, University of the Witwatersrand, Private Bag 3 Johannesburg, 2050, South Africa.

${ }^{3}$ Environmental Change Research Centre, Department of Geography, Pearson Building, University College London, Gower Street, London, WC1E 6BT, United Kingdom.

* Corresponding author:

Email: jennifer.m.fitchett@gmail.com

Phone: (+27) 725506829

\begin{abstract}
Over recent decades, concern has been raised regarding the management of Chrysocoma ciliata L. (Asteraceae syn. C. tenuifolia) in the eastern Lesotho highlands. This shrub species is argued to be a Karroid invasive introduced anthropogenically within the last century. Historical botanical records in Lesotho are scarce, so the origins of this species in the region are as yet uncertain. Speculation is based on the contemporary abundance of these shrubs in overgrazed areas throughout the highlands. This study presents fossil pollen records for the eastern Lesotho Highlands which confirm the presence of this species intermittently throughout the past $\sim 6,000$ cal yr BP. In so doing, this study refutes claims that the species was introduced anthropogenically within the past 100 years, and of its narrow definition as a Karoo species invasive in Lesotho. The intermittent appearance of this species in the pollen record, however, indicates that it is climate sensitive, colonising the wetlands under conditions unsuitable to other plant species. Evidence presented here calls for a re-evaluation of the categorisation of Chrysocoma ciliata as an invasive in the Lesotho highlands, and more critically, for a redevelopment of the environmental management policies which involve this species.
\end{abstract}

Keywords: Chrysocoma ciliata, invasives, eastern Lesotho, pollen.

Acknowledgements: The authors thank Professor Louis Scott for his assistance in the identification of the Chrysocoma ciliata pollen grains, and for his provision of the photographs 4D-J included in this manuscript. This work was funded by the National Research Foundation of South Africa and the DST/NRF Centre of Excellence for Palaeoscience. 


\section{Introduction}

One of the key conservation management concerns of the $21^{\text {st }}$ century is the spread of invasives, the resultant disruption of local ecosystems, and the eventual extirpation of native species (Colautti and MacIsaac 2004; Willis et al. 2007; Froyd and Wills 2008). However, critical to the success of such management, and ultimately ecologically appropriate restoration of an ecosystem, is the accurate attribution of the provenance of each component species (Van Leeuwen et al. 2008; Van Der Knaap et al. 2012). Native species are defined as those which have not been accidentally or deliberately introduced to the region (Bean 2007; Froyd and Willis 2008), and which are presently located in the region of their evolutionary origin (Colautti and MacIsaac 2004; Willis and Birks 2006). Broad criteria for determining whether a species is native to a region include historical evidence for its presence, the habitat, the contemporary geographical distribution, the ease of naturalisation, genetic diversity, the reproductive pattern, and possible means of introduction into the region (Webb 1985; Van Leeuwen et al. 2005; Joubert 2009; Wilmshurst et al. 2015). Ecological studies of invasive species increasingly recognise the importance of consulting historical records, yet these often are limited to herbarium specimens and aerial photographs, with few studies of invasive species consulting databases spanning periods greater than a few decades (Ornerod et al. 1999; Froyd and Willis 2008; Wilmshurst et al. 2013; Martin et al. 2014). These comparatively short-term records, relative to the periodicity of environmental and climate cycles, make it difficult to disentangle long term trends in biogeographic ranges from the more short-term variability (Willis and Birks 2006; Wilmshurst et al. 2013, 2015). Fossil pollen records spanning the mid- to late-Holocene have been proposed as a mechanism to provide evidence of the presence or absence of 'doubtful natives' prior to the commencement of anthropogenic alteration of a region (cf. Basset and Terasmae 1962; Cruzan and Templeton 2000; Van Leeuwen et al. 2005, 2008; Willis and Birks 2006; Willis et al. 2007; Gillson et al. 2008; Petit et al. 2008; Froyd and Willis 2009; Wilmshurst et al. 2013, 2015; Dietl et al. 2015). The uptake of this approach, however, has been slow (Froyd and Willis 2008; Gillson et al. 2008; Wilmshurst et al. 2013; Dietl et al. 2015), with limitations including relatively poorly constrained chronologies, and the broad spatial resolution of fossil pollen records. Such an approach critically engages with key debates in palaeoscience, as among the 50 priority research questions in ecology (Seddon et al. 2014: 259) is "How can the palaeoecological record be applied to understanding the interactions between native, alien and invasive species?".

The most severe limitations in using of fossil pollen to resolve debates regarding the classification of contentious species as native or invasive stem from the level of taxonomic resolution possible, and the size of the pollen rain catchment area (Cruzan and Templeton 2000; Willis and Birks 2006). In geographical regions where the potential range of pollen rain is limited due to topography such as islands or very high altitude mountainous environments, and in cases where a pollen grain for the species in question has particularly distinctive features or where only one species of an identifiable genus is present in the contemporary environment, palynological studies of a continuous sediment record can provide a datable record of the presence of a species (Van Leeuwen et al. 2005; Dietl et al. 2015). This approach was first used to determine whether the contemporary weed Ambrosia spp. was indeed an invasive in Canada, with the presence of those pollen grains throughout the profile confirming its native presence, but with considerably greater proportions following intensive agricultural development in Canada (Basset and Terasmae 1962). In this case, supporting pollen evidence for the broader vegetation community demonstrated that the population size of Ambrosia spp. was 
directly linked to the forest extent, which declined rapidly as large areas were cleared for agriculture (Basset and Terasmae 1962). However, as this palynological evidence was based on percentage composition rather than concentration or fluxes, these results could be disputed by present standards. Similarly, in the Azores Islands, Selaginella kraussiana was commonly classified as an invasive species, yet palynological analyses confirmed its presence in the pollen record dating back to 6,000 cal. yr BP (Van Leeuwen et al. 2005). A subsequent study of island vegetation found a list of six supposedly invasive species which were present in the pollen records for thousands of years prior to human occupation (Van Leeuwen et al. 2008). By contrast, through pollen analysis, Preston et al. (2004) found over 157 plant species that emerge in Britain between 4,000 cal. yr BP and 500 cal. yr BP. The timing of the appearance of these species in the pollen record coincides with human presence in the region, yet it is unlikely that these plant introductions were deliberate in the contemporary sense (Preston et al. 2004; Willis and Birks 2006). Such invasions have therefore been given a further classification of 'archaeophyte invasions' (Preston et al. 2004; Chytrý et al., 2008).

As the eastern Lesotho highlands are situated in the Drakensberg Alpine Centre, a region hosting a large number of endemic species and with highly climate sensitive marginal communities due to the high altitude $(>2,800$ m.asl) (Carbutt and Edwards 2004; 2006), it is imperative that management decisions concerned with the restoration of the natural environment are based on robust scientific information. The protection of large proportions of endemic species, and the environmental stressors to native species through topography and climate, both heighten the potential damage that invasive species could cause. Chrysocoma ciliata, a drought resistant perennial shrub species, is the subject of conservation management concern in the eastern Lesotho Highlands, as it is believed to be an invasive derived from the Karoo region located at considerably lower altitude and some 400km to the southwest (Van Zinderen Bakker, 1981; Grab and Nüsser 2001; Nüsser and Grab 2002; Grab and Deschamps 2004). This study presents palynological evidence for the intermittent presence of Chryscocoma sp. dating prior to 4,000 cal. yr BP from a sediment core extracted near Sani Top, eastern Lesotho. We argue on the basis of this evidence that Chrysocoma ciliata is not an invasive species, but rather a native species which proliferates under harsh climatic conditions unsuitable to the presently more ubiquitous grasses, sedge and Helichrysum communities.

\section{Chrysocoma ciliata: the state of knowledge}

Chrysocoma ciliata is a small woody shrub species, characterised by dark green leaves and small yellow flowers (Figures 1a,b; Deschamps 2006). The species is alternately referred to both among locals and within the literature as Chrysocoma tenuifolia (cf. Jacot Guilarmod, 1971; Killick 1978; Schwabe and Whyte 1993), Chrysocoma obliqufolia (cf. Pooley 1998), and 'Sehlahala' (Morris et al. 1993); it has been confirmed that all four terms refer to the same species (cf. Grab and Deschamps 2004). Chrysocoma ciliata is insect pollinated, but due to the small size of the pollen grains, the pollen rain is easily distributed by wind (Mayer et al., 2006). In the contemporary landscape of eastern Lesotho, these shrubs colonise over-grazed areas with an otherwise degraded land surface (Figure 1b; Grab and Deschamps 2004; Grundling et al. 2015; Kopij 2015), and are abundant in the immediate area surrounding abandoned cattle posts (Figure 1a; Morris et al. 1989) and along intensively used sheep and cattle tracks. It is for this reason that it is widely assumed that the species was introduced into the region at the onset of extensive cattle grazing some 100 years ago (Van Zinderen Bakker 1955; Killick 1978; 
Grab and Deschamps 2004; Grundling et al. 2015). In vegetation transects undertaken near Sani Top, eastern Lesotho, Chrysocoma ciliata was only found along transects spanning gullied valley heads (Grab and Deschamps 2004). It is estimated that in 1938, Chrysocoma ciliata comprised the predominant plant cover for at least $13 \%$ of the mountain area of eastern Lesotho (Killick 1963), and that by 1998, the shrubs covered $16 \%$ of the rangeland in eastern Lesotho, comprising approximately 360,000 hectares (Marake et al. 1998). More recent measurements of the rate of establishment of Chrysocoma ciliata indicate persistent cover on the east facing slope of Hodgson's Peak (Figure 2) from December 2009 to December 2011, but an increase on the west facing slope from $4.8 \%$ to $9.8 \%$ respectively over this period (Robinson, 2014). The tendency for this species to colonise areas of degraded vegetation, and its rapid proliferation, has resulted in concerns regarding its effect on, and management for, conservation of the natural biota (Grab and Nüsser 2001; Nüsser and Grab 2002).

The provenance of Chrysocoma ciliata populations in eastern Lesotho remains debated, with its attribution in the literature as an invasive or Karroid invasive, and by contrast a native species (Table 1). The attribution of Chrysocoma ciliata as an invasive species appears to relate to the nature and speed of its propagation under conditions unsuitable for other species, a characteristic trait of invasives (Van Zinderen Bakker 1955; Killick 1978; Grab and Deschamps 2004; Grundling et al. 2015). It is, however, notable that Chrysocoma ciliata is poisonous to certain livestock and unpalatable to most (Killick 1990; Rutherford et al. 2012), and thus the abundance of this species in commonly grazed areas may rather reflect avoidance patterns in fodder selection (Morris 1989; Grab and Nüsser 2001). In a comprehensive botanical survey of the Drakensberg Alpine Centre, Carbutt and Edwards (2004) list Chrysocoma ciliata among the $\sim 2800$ specific native taxa of this $40,000 \mathrm{~km}^{2}$ exclusively high altitude region.

Although arguably not a Karroid invasive, but perhaps native to the eastern Lesotho Highlands, Chrysocoma ciliata is undisputed to be found in the contemporary vegetation of the Karoo (Schalke 1973; Squires and Trollope 1979; Anderson and Hoffman 2007; Rutherford et al. 2012). In addition, Chrysocoma ciliata is described as a component of the contemporary vegetation of the Eastern Cape (Cowling 1983; Brand et al. 2008), Free State Drakensberg (Daemane et al. 2010), and western Lesotho lowlands (Esterhuysen and Mitchell 1996). It is unclear whether any, or all, of these areas represent the sole ecological native region for this species. Across all these regions, the species is able to proliferate under drought conditions, and thrives in environments with little other vegetation cover (Letšela et al. 2008; Rutherford et al. 2012).

The importance of accurately determining the provenance of Chrysocoma ciliata populations in eastern Lesotho lies in facilitating ecologically responsible management decisions (Froyd and Willis 2008; Carbutt 2012). Due to the proliferation of these shrubs within over-grazed grasslands and degraded wetlands, management suggestions have included the removal of these species as they are believed to pose a threat to the biodiversity of the region owing to their rapid proliferation and abundance in degraded environments perceived to result in outcompeting the indigenous species (Killick 1990; Grab and Deschamps 2004; Grundling et al. 2015). Furthermore, as Chrysocoma ciliata provides considerably less biomass than native-classified grasses in the region $(280.1 \mathrm{~kg} / \mathrm{Ha}$ versus $1875.7 \mathrm{~kg} / \mathrm{Ha})$, their removal from the region and the deliberate support of grass renewal has been supported (Schwabe and Whyte 1993; Robinson 2014). Such management approaches have 
been seldom implemented, even though the eastern Lesotho highlands represent one of the most endemic-rich regions within the Drakensberg Alpine Centre (DAC), only 1\% of the Lesotho Highlands Grassland belt is statutorily conserved, and much of the management of the natural environment is undertaken through transhumance systems (Du Preez \& Brown, 2011). However, if the species is native to the region, its removal may prevent successful feedback systems from occurring, following the degradation of an area, and thus delay or prevent its renewal. Furthermore, the existence of the species in both the low-altitude regions of western Lesotho and the Karoo, and in the very high altitude eastern Lesotho Highlands, suggests that it has a particularly large tolerance of both drought and a wide temperature range. It is therefore of importance to determine the provenance of this species to better inform management decisions and to improve our understanding of plant species endemic, native and exotic to this marginal environment.

\section{Study Site}

The Sani Valley site for this study is located approximately $5 \mathrm{~km}$ west of the Sani Top border post, directly adjacent to the Mokhotlong road and south of the Sani River, at an altitude of 2,900 m.asl (Figure 2). The site, spanning a maximum length of $\sim 280 \mathrm{~m}$ and width of $\sim 80 \mathrm{~m}$ represents a large wetland compared to the smaller ( $\sim 10 \mathrm{~m}$ diameter) wetlands more typical in eastern Lesotho, with a large area of meadow-grasses and sedges surrounded by gently undulating basalt hills. The underlying geology for the eastern Lesotho Highlands region is flood basalt, $\sim 180 \mathrm{Ma}$ in age. Although occasional dolerite and kimberlitic pipe intrusions occur in places, there are no such intrusions near the study site. The wetland centre has a raised bog with surface moisture at the summit, even during the dry season (similar to those described by Schwabe 1995). This mound appears to represent a hydralaccolith, and is probably situated above the intersection of large lineations giving rise to the spring (Mills et al. 2009) and associated cryogenically raised mound. The position of the eastern Lesotho Highlands adjacent to te highest portions of the Great Escarpment, and the topography comprising a complex network of steeply sloping mountains, prevents the transport of pollen by wind from much of the lower altitude regions of adjacent South Africa (Van Zinderen Bakker 1955; Grundling et al. 2015). While the catchment area of pollen is quite large, reducing the spatial resolution of results (Van Leeuwen et al. 2005), in the case of the eastern Lesotho Highlands, it can be considered representative of high altitude marginal vegetation (Van Zinderen Bakker 1955; Carbutt and Edwards 2004).

The contemporary climate of eastern Lesotho has a distinct seasonal alpine climate with cool wet summers and cold dry winters (Grab 2010). Mean annual air temperature estimates for Sani Top range from $3-7^{\circ} \mathrm{C}$ (Borg 2012), while mean annual rainfall for Sani Top ranges from $750 \mathrm{~mm} / \mathrm{yr}-1600 \mathrm{~mm} / \mathrm{yr}$ (Nel and Sumner 2005; Mills et al. 2009). Most precipitation above $3,000 \mathrm{~m}$.asl between May and September falls as snow, but accounting for less than $10 \%$ of total annual precipitation (Nel and Sumner 2008), with an average of 2-8 moderate to light snowfalls per year (Grab and Linde 2014). Frost is a common occurrence in the autumn, winter and spring months (Mills et al. 2009). The hills surrounding the wetland provide some protection from the regionally dominant strong westerly winds. 
The alpine belt of eastern Lesotho, from 2,865-3,482 m.asl, is classified as a grassland biome (Lesotho Highland Basalt Grassland, GD8) with both tussock and meadow grasses, dominated by Merxmuellera, Festuca, Danthonia and Pentaschistis species, and interspersed by the small woody shrubs Erica and Helichrysum (Jacot Guilarmod, 1971; Backéus 1989; Nüsser and Grab 2002; Mucina et al., 2006; Grab 2010). The broader region is classified as the Drakensberg Alpine Centre (DAC; Carbutt and Edwards 2004). The Sani Top area has a relatively large diversity of vegetation, ranging from grass and herbs, to sedges more indicative of wetland conditions, and semi-aquatic to aquatic species in the open water, many of which are endemic to the DAC. Notably, the contemporary vegetation both at the sampling site and in the broader Sani Top region includes Chrysocoma ciliata. The site is home to a large population of ice rats (Otomys sloggetti robertsi) (genus and species) that are thought to be responsible for soil erosion and diminished size of plants at the site (Mokotjomela et al. 2009). There is considerable grazing pressure from sheep, cattle and horses in the area, which together with their associated trampling, results in loss of vegetation and soil erosion (Mokotjomela et al. 2009).

\section{Methods}

A $1.2 \mathrm{~m}$ sediment core was extracted from the raised bog at Sani Top using 75mm-diameter PVC tubing. The core was sealed using plastic 'cling-wrap' and transported back to the laboratory where it was refrigerated at $\sim 4^{\circ} \mathrm{C}$ until use. The core was sectioned at $3 \mathrm{~cm}$ intervals in a pressure-controlled laboratory to prevent contamination. Four bulk organic material samples from relatively equally spaced depths throughout the core were sent for Accelerator Mass Spectrometer (AMS) radiocarbon dating at Beta Analytic (Table 1). These dates were calibrated using the Southern Hemisphere SHCal13 model (Hogg et al. 2013). The BACON model (Blaauw and Christen 2011) was used to interpolate dates for the remainder of the profile. This model was selected given its improved performance of Bayesian over linear regression models, and the inclusion of information on sample thickness (Mackay et al. 2013). A fifth sample from the base of the core was sent for AMS dating, but provided an erroneous date and is thus excluded.

Pollen preparation of 30 samples followed standard procedures outlined by Faegri et al. (1989) with pollen grains mounted using glycerol jelly and slides stored in the Evolutionary Studies Institute of the University of the Witwatersrand. Once the pollen had been isolated and slides prepared, a minimum of 250 pollen grains were counted per sample at a magnification of 400x using an Olympus BX51 light microscope. Identification was made with reference to the African Pollen Database, and the Louis Scott collection at the University of the Free State, Bloemfontein, South Africa. Key pollen grains were photographed at 1000x magnification under oil immersion using standard brightfield and Nomarski DIC with a calibrated scale bar included. A square-root transformation was applied to all pollen count data, to stabilize species variance and prevent excessive influence of dominant species (Mackay et al. 2013). Pollen relative abundances were plotted against age using the stratigraphical plotting software C2 (Juggins 2007). Important gradients in the pollen record were explored using the indirect ordination technique of Principal Components Analysis (PCA), and zonation was performed using Constrained Incremental Sum of Squares (CONISS), both undertaken using the code-based statistical platform R (Venables and Smith 2015). 


\section{Results}

The profile of the core demonstrated a high percentage organic content throughout $(>30 \%$ for 34 samples; $>60 \%$ for 13 samples), comprising a mixture of organic rich clays and peat. Accordingly, sediments were dark in colour (10YR 2/2- 10YR3/3). Percentage carbonate content remained particularly low throughout the profile, ranging from $0.5 \%$ at $\sim 2,970$ cal. $\mathrm{yr}$ BP to $6.3 \%$ at $\sim 1,690$ cal yr BP. The mean particle size was $3.54 \Phi$ units, with the profile dominated by silt-sized particles.

Four radiocarbon AMS ages were obtained for the Sani Valley profile (Table 3) and are detailed in Table 3, alongside their calibrated ages. The age of the bottom of the core is unknown, but from interpolations using the BACON model (Figure 3) and from fluctuations in rates of accumulation in a dated profile from the nearby Sekhokong site, the bottom of the core is very approximatelyestimated to date to $\sim 6,200$ cal. yr BP, providing an age-depth profile consistent with those for other sites in the eastern Lesotho Highlands (Van Zinderen Bakker and Werger 1974; Marker 1994). The minimum age of the bottom sediments is taken as $>3,990$ cal. yr BP.

The BACON model estimates the mean accumulation rate throughout the sequence to 40yr.cm-1 (Figure 3). Notable is a period of very slow sediment accumulation in the middle of the sequence, from 1,610 $\pm 30 \mathrm{cal}$. $\mathrm{yr}$ BP to $3,990 \pm 30$ cal. yr BP, during which time only $19 \mathrm{~cm}$ of sediment accumulated, with a mean rate of 125yr.cm-1. Comparatively more rapid and consistent sediment accumulation occurred subsequent to, and following, this period.

Pollen grains from a total of 25 taxa were identified from the 30 samples (Table 3). Due to morphological and environmental similarities, pollen counts from the plant families Chenopodiaceae and Amaranthaceae are summed to form a single group 'Cheno-Am' (Scott et al. 2012). The sequence is dominated by Cyperaceae, with high proportions of Asteraceae and Poaceae. Plant families that represent 1\% or more of the profile include Crassula, Aizoaceae, Cheno-Am (Chenopodiaceae-Amaranthaceae types), Caryophylaceae and Apiaceae (Table 4). The pollen assemblage is indicative of conditions similar to the contemporary environment, comprising a large bog with meadow grasses and scattered communities of small shrubs persisting throughout the mid- to late-Holocene at this site.

The CONISS output for the pollen results from the Sani Valley site divides the profile into three groups, named here as SAP1, SAP2 and SAP3 (Figure 5). The division between SAP1 and SAP2 occurs at a relatively shallow mean depth of $16 \mathrm{~cm}(<200$ cal. yr BP), while SAP2 and SAP3 are separated at a mean depth of $55 \mathrm{~cm}(\sim 1,390$ cal. yr BP). Analysing the PCA bi-plot for the pollen results from Sani Top (Figure 6), the Chrysocoma ciliata vector is closely correlated with those of Cheno-Am, Poaceae, Pentzia and Vernonia, with positive PC1 and PC2 scores. Notably, Cheno-Am, Pentzia and Vernonia are known to be drought tolerant species, and in the context of the eastern Lesotho wetlands, a greater relative abundance of Poaceae relative to Cyperaceae indicates a shift to drier wetland conditions (Van Zinderen Bakker, 1955; Fitchett et al., 2016). PC1 accounts for a statistically significant $36.2 \%$ of the variance in samples on the basis of their pollen species distribution. PC1 species scores are ordered at extremes from Cyperaceae, with large negative PC1 scores, to Cheno-Am, Poaceae, Pentzia and Vernonia and undifferentiated Asteraceae with large positive PC1 scores. 
SAP3 ( 6,200-1,400 cal. yr BP) is dominated by Cyperaceae, with percentages of Asteraceae and Poaceae pollen remaining below $20 \%$ for much of the zone (Figure 5). A notable decrease in the PC1 curve, shifting to negative values, occurs at $\sim 4,460$ cal. yr, BP, driven by a peak in Cyperaceae and the lowest percentage of Asteraceae throughout the zone. The zone has the greatest taxon diversity within the profile, and appears to indicate warm, wet conditions, with small pulses of drought episodes and a transition to dry conditions at its termination. SAP2 ( 1,350-200 cal. yr BP) reflects the greatest relative abundance of Asteraceae pollen throughout the sequence, paired with a lower percentage composition of Cyperaceae (Figure 5). The proportional representatioon of Poaceae is relatively high, but continues to fluctuate throughout this zone. The commencement of the zone $(\sim 1,350$ cal. yr BP) is marked by a peak in Crassula, Olea, Indigofera, Caryophylaceae and Cyperaceae, but low proportions of Asteraceae and Poaceae, suggesting a short-lived particularly moist period (Figure 5). The PC1 curve is positive for much of SAP2, tracking the larger proportions of grassland and shrub components in place of sedges, indicative of comparatively drier conditions overall. SAP1 ( 145 cal. yr BP - present), similar to SAP3, is dominated by Cyperaceae, which increases rapidly from $\sim 60 \%$ of the pollen count to just under $80 \%$ in the modern samples (Figure 5). The relative abundance of Asteraceae is particularly low, but largely stable during this period. By contrast, the relative abundance of Poaceae varies considerably, with peaks exceeding $20 \%$ at the beginning and end of the zone, separated by a minimum abundance of $7.4 \%$ at $<100$ cal. yr BP. This decrease in Poaceae occurs concurrently with an increase in Crassula, which remains relatively abundant throughout this zone. The predominance of Cyperaceae would suggest moderately wet conditions throughout this zone.

In many instances, the taxonomic resolution was constrained to the family level due to indistinguishable features between genera. However, in the case of the Asteraceae family Vernonia spp., Pentzia spp. and Chrysocoma spp. could be identified and were counted separately to the broader Asteraceae group. For the genus Chrysocoma, the only species growing within the contemporary pollen rain catchment area of the sampling site is Chrysocoma ciliata (Hill, 1992; Brand et al., 2008; Rutherford et al., 2012; Scott, pers comm., 2014). Therefore, the pollen grains identified and counted as the morphologically distinguishable Chrysocoma genus (Figure 4a-c) could be attributed to the species Chrysocoma ciliata. These pollen grains are consistent with reference pollen, specifically from Chrysocoma ciliata from the Louis Scott collection (Figure 4D-F). The only published record of Chrysocoma sp. pollen is under a synonym (Ifloga) for the species Ifloga spicata in Egypt (Osman 2011), for which the morphology is consistent. Pollen grains from Chrysocoma sp. were observed at a mean relative abundance of $0.2 \%$ throughout the core, with a maximum relative abundance of $1.2 \%$ (Table 4 ).

Chrysocoma ciliata pollen grains are tricolporate, tectate, resulting in a fairly thick wall. They are oblate spheroidal to spheroidal in shape with the polar axis 30-50 $\mu \mathrm{m}$ and equatorial axis 32-70 $\mu \mathrm{m}$, with a notable decrease in size for the eastern Lesotho samples. The colpi are long, wide and shallow with small pores. The exine is medium -thick and the surface is covered with spines with the base wider than the height, about $3 \mu \mathrm{m}$ high. Spines are pointed and slightly concave with numerous small spots that probably represent holes or perforations, and the surface in between is granulate (Figure 4A-J). Chrysocoma ciliata pollen can be distinguished from the other local species (C. polygalaefolia; Fig 4g) which has fewer spines. It can also be 
distinguished from Helichrysum species based on size, as the latter is larger and has spines that are much more closely spaced or longer (Figure 4H-J). Vernonia pollen types do not have the compact spines typical of Chrysocoma, while Pentzia have considerably longer spines (see illustrations in Scott 1982).

As demonstrated in the stratigraphic plot presenting the relative abundance of the observed pollen grains against time, Chrysocoma sp. pollen appears intermittently in small relative proportions throughout the profile (Figure 5). The first appearance of the Chrysocoma sp. pollen grain is in the bottom-most subsample of the core at a depth of $111 \mathrm{~cm}$, with a basal age of $>4,000 \mathrm{cal} \mathrm{yr} \mathrm{BP}$, and an interpolated age from the BACON model of $\sim 6,000$ cal. yr BP. Chrysocoma sp. pollen re-appears some 1,200 years later in a subsample obtained from a depth of $82.5 \mathrm{~cm}(\sim 4,770$ cal. yr BP), followed by a second relatively equal absence of $\sim 1,100$ years. Chrysocoma sp. pollen appears more frequently in the upper half of the core, in sediments spanning in age from $\sim 3,000$ cal. yr BP to present (Figure 5). A total of 8 subsamples contained Chrysocoma pollen grains in this portion of the core, with a mean absence period between Chrysocoma bearing samples of $\sim 800$ years. Greater relative abundances of Chryscoma sp. pollen are observed in this half, with two consecutive peaks at $\sim 1,970$ and $\sim 1,490$ cal. yr BP respectively. Notably, during this period, the relative abundance of semi-aquatic Cyperaceae was at a minimum; reflecting a drier period. While there are slight similarities in the fluctuations of Poaceae and Chrysocoma sp., no taxon demonstrates a distinct pattern of covariance with this species.

\section{Discussion}

The pollen record from Sani Top provides the first evidence for the intermittent existence of Chrysocoma sp. in eastern Lesotho dating back to $\sim 6,000$ cal. yr BP. While the bottom date of the core is an interpolated value produced by the BACON model, the sub-sample from a depth of $78 \mathrm{~cm}$ is AMS radiocarbon dated to 3,990 cal. yr BP. Therefore, with greater certainty, the results from the pollen analysis of the peat core extracted from Sani Top provides evidence that Chrysocoma sp. were present in the eastern Lesotho Highlands prior to 3,990 cal. yr BP. These findings are in direct conflict with a the majority of the existing literature, that assumes, if not argues, that the species is an invasive to the eastern Lesotho Highlands (Table 1). In particular, on the basis of this evidence, we dispute the claims that the species was anthropogenically introduced into the region from c. AD 1890, the time from which the highlands were used more extensively for livestock grazing, and which was assumed to be the cause of the introduction of the species (Van Zinderen Bakker 1981; Grab and Deschamps 2004; Showers 2005; Brand et al. 2015). While Parker et al. (2011) present archaeological evidence for livestock in the eastern Lesotho Highlands dating back considerably further to 1,070 cal. yr BP, we record Chrysocoma sp. in the Sani Top pollen record pre-dating this time.

The term 'native species' has been argued to refer particularly to those which have not been anthropogenically introduced to an area deliberately or accidentally (Bean 2007; Froyd and Willis 2008; Joubert 2009). Therefore, while the fossil pollen evidence presented in this study would contest the accidental or deliberate introduction of Chrysocoma ciliata into the eastern Lesotho Highlands $\sim 150$ years ago at the commencement of intensive grazing, it is more difficult to prove that the species was not accidentally introduced to the area many years before this. Archaeological evidence for the eastern Lesotho Highlands confirms Stone Age occupation dating back to >80,000 cal. yr BP (Mitchell 1996; Stewart et al. 2012; Roberts et al. 2013). As the pollen record 
presented in this study does not pre-date these periods of Stone Age occupation in the region, it is not possible to prove at this point that Chrysocoma ciliata existed in the region prior to any human occupation. However, this too holds true for much of the world, with the exception of uninhabited islands (Van Leeuwen et al. 2005). Thus, the species could tentatively be assigned the classification 'archaeophyte invasive' (Preston et al. 2004; Chytrý et al., 2008). However, it should be noted that the archaeological evidence for seasonal migration between the eastern Lesotho Highlands and lower altitude regions in South Africa is concentrated in the KwaZulu-Natal region to the east of Lesotho, rather than in the Karoo to the west (Carter et al. 1988; Mitchell 1995). Therefore, if Chrysocoma was accurately classified as an archaeophytee invasive, their attribution in the literature as a Karroid invasive should be disputed.

The intermittent appearance of Chrysocoma sp. in the pollen record is of further interest. First, if the species were not native to the region, the re-appearance in the pollen record would require repeated non-deliberate introductions into the region, which seems probabilistically unlikely. Second, the periods of appearance coincide in all cases with periods of depreciated relative abundance of the semi-aquatic Cyperaceae family (Figure 5). This is also reflected in the strong association of Chrysocoma ciliata and other drought resistant taxa in the first principal component. It would therefore appear that this species is relatively drought resistant, . This confirms Carbutt's (2012) classification of Chrysocoma ciliata as a native species which under certain climateenvironmental conditions becomes weedy within its native range. Such climate-environmental conditions are either coincidentally or causally related to changes in the vegetation cover in the eastern Lesotho Highlands region, as would be indicated in the pollen record, and the resultant changes in vegetation cover at specific locations such as gullies and abandoned cattle posts (Figure 1; Van Zinderen Bakker, 1981; Grab and Deschamps 2004). For example, it has been recorded that following the drought of 1932-1933, Chrysocoma ciliata dominated the previous grassland region of eastern Lesotho (Letšela 2008). The reason for this period of population explosion necessarily requires that Chrysocoma ciliata is particularly drought resistant; yet its disappearance from the pollen record would suggest that this species cannot thrive without the more dominant vegetation having already receded (Quinlan and Morris 1994). Under particularly moist climatic conditions the size of the eastern Lesotho wetlands would increase, with greater surface water available (Van Zinderen Bakker, 1955, 1981; Fitchett et al., in press). This would support increases in semi-aquatic taxa such as Cyperaceae and Apiaceae, and the moisture would support the re-establishment of grasslands. These plants would then outcompete Chrysocoma ciliata, resulting in its disappearance from the pollen record.

While the findings of this study disprove claims that Chrysocoma ciliata is a Karroid invasive introduced to the eastern Lesotho highlands $\sim 150$ years ago, it raises further questions. The first question pertains to the size and characteristics of the native habitat of the species. One possibility is that there was a continuum in the native habitat of Chrysocoma ciliata spanning from the Karroo through to the eastern Lesotho Highlands. This would be supported by contemporary populations of Chrysocoma ciliata in the western Lesotho lowlands (Esterhuysen and Mitchell 1996; Grab et al. 2005), forming a relatively uninterrupted ecological corridor. The second possibility is similar to the first, in that at some point a continuous population of Chrysocoma ciliata spanned the area from contemporary eastern Lesotho to the Karoo, but that eastern Lesotho developed into a separate refuge (Cruzan and Templeton 2000; Petit et al. 2008). This would explain the capacity of the species to 
withstand the very cold temperatures and high incidence of snow and severe frost for several months of the year, co-habiting with many species that are ecologically adapted to these conditions (Van Zinderen Bakker 1955; Nüsser and Grab 2002). The third possibility is that the species was introduced to the region via long distance migration (Cruzan and Templeton 2000). This option would include the possibility of accidental introduction via seasonally migrating Stone Age occupants of eastern Lesotho. Further work of this nature using much longer palaeoenvironmental reconstructions would be required to address these questions.

The second set of questions relates to the historical fluctuations in abundance and absence, and the link to the contemporary patterns of proliferation of Chrysocoma ciliata. What is known at this point, based on the historical commentary (Letšela 2008) and the contemporary landscape (Grab and Deschamps 2004), is that Chrysocoma ciliata survives under drought conditions. This is consistent with the patterns of coinciding species in the palaeoenvironmental record (Figure 5). In the contemporary environment, Chrysocoma ciliata proliferates in areas which have been severely environmentally degraded, including landscapes subject to over-grazing, gullying and trampling, and in desiccated wetlands (cf. Beverly 1980; Killick 1990; Grab and Deschamps 2004; Du Preez and Brown 2011; Brand et al. 2015; Kopij 2015). As hypothesised above, this may be due to Chrysocoma ciliata requiring a decrease in the surrounding vegetation cover to thrive (Quinlan \& Morris, 1994). However, management concerns surround the role of Chrysocoma ciliata in preventing the natural reestablishment of the grasslands following environmental degradation, and thus the longer-term threats to the natural ecosystem (Nüsser and Grab 2002; Grundling et al. 2015). Arguably, however, as Chrysocoma ciliata is not palatable to livestock (Morris et al. 1993; Grab and Nüsser 2001), the proliferation of this species may provide the natural ecosystem with an opportunity to re-establish itself under conditions of decreased livestock influence.

An improved understanding of the provenance of Chrysocoma ciliata, and the environmental drivers for its relative absence and proliferation in the eastern Lesotho Highlands, is critical to facilitate ecologically sound conservation management protocols. While there is valid concern regarding the current proliferation of Chrysocoma ciliata in the eastern Lesotho Highlands, and associated implications on long-term ecosystem health, little work has been undertaken to project the future nature and extent of the population (Rouget et al. 2004; Carbutt 2012). Furthermore, as the contemporary climatic preferences of the eastern Lesotho population of Chrysocoma ciliata are not yet known, future declines of this species are difficult to model. These issues are addressed, at least in part, through a better understanding of the provenance of this 'doubtful native' and a better concept of the biodiversity baseline for the region (Willis et al. 2007, 2008). However, the questions raised in this paper regarding the circumstances and timing of the introduction of Chrysocoma ciliata into the eastern Lesotho Highlands, given the continued presence in the fossil record, and of the environmental preferences of the species, require urgent research attention to improve both invasive plant programmes and the management of the grazing system (Quinlan and Morris 1994; Vetter et al. 2006; Carbutt 2012).

\section{Conclusion}

This study presents the first evidence of the presence of Chrysocoma ciliata in the eastern Lesotho Highlands prior to the introduction of livestock grazing to the region in the 1800 s. This evidence disputes claims that the 
species is an invasive, introduced to the region during the $19^{\text {th }}$ century. Rather, Chrysocoma ciliata has occupied the eastern Lesotho Highlands sporadically throughout at least the past 3,990 cal. yr BP, consistent with Carbutt's (2012) classification of the species as native to the eastern Lesotho Highlands. While it is possible that this species was introduced to the region accidentally by Stone Age occupants prior to $\sim 6,000 \mathrm{cal} \mathrm{yr} \mathrm{BP}$, in which case it should be re-classified as an archaeotype invasive, the archaeological evidence for the geographical patterns of this seasonal migration do not support the inferences of human introduction of the species from the Karoo. We contend that the Chrysocoma ciliata population of the eastern Lesotho Highlands may represent a sub-community of the species, specifically adapted to the harsh high altitude climate. While this study confirms that the species was not introduced within the last $\sim 150$ years, it does pose numerous questions regarding the evolutionary dissemination of this species, and the contemporary conditions which support its proliferation.

\section{References}

Anderson PML, Hoffman MT (2007) The impacts of sustained heavy grazing on plant diversity and composition in lowland and upland habitats across the Kamiesberg mountain range in the Succulent Karoo, South Africa. Journal of Arid Environments 70: 686-700.

Backéus I (1989) Flarks in the Maloti, Lesotho. Geografiska Annaler, Series A, Physical Geography 71(1): 105111.

Basset IJ, Terasmae J (1962) Ragweeds, Ambrosia species, in Canada and their history in postglacial time. Canadian Journal of Botany 40: 141-150.

Bean AR (2007) A new system for determining which plant species are indigenous in Australia. Australian Systematic Botany 20: 1-43.

Beverly AC (1980) The ecological status and environment of Aloe polyphylia in Lesotho. Cactus and Succulent Journal 52: 1-5.

Blaauw M, Christen JA (2011) Flexible paleoclimate age-depth models using an autoregressive gamma process. Bayesian Analysis 6(3): 457-474.

Borg C (2012) Mechanisms controlling valley asymmetry development at Abisko Northern Sweden and Sani Pass, Southern Africa. Geotrycheriet Uppsala University, Uppsala.

Botha CJ, Venter E (2002)

Chrysocoma. http://repository.up.ac.za/bitstream/handle/2263/8519/toxp_101.JPG?sequence=1 andisAllo wed=y. Accessed 20 January 2016.

Brand RF, Du Preez PJ, Brown LR (2008) A floristic description of the Afromontane Fynbos communities on Platberg, Eastern Free State, South Africa. Koedoe 50(1): 202-231.

Brand RF, Collins N, Du Preez PJ (2015) A phytosociology survey and vegetation description of inselbergs in the uKhahlamba-Drakensberg Park World Heritage Site, South Africa. Koedoe 57(1). doi: 10.4102/koedoe.v57i1.1233.

Carbutt C, Edwards TJ (2004) The flora of the Drakensberg Alpine Centre. Edinburgh Journal of Botany 60(3): 581-607.

Carbutt C, Edwards TJ (2006) The endemic and near-endemic angiosperms of the Drakensberg Alpine Centre. South African Journal of Botany 72: 105-132. 
Carbutt C (2012) The emerging invasive alien plants of the Drakensberg Alpine Centre, southern Africa. Bothalia 42(2): 71-85.

Carter PL, Mitchell PJ, Vinnicombe P (1988) Sehonghong: The Middle and Later Stone Age industrial sequence at a Lesotho rock-shelter. British Archaeological Reports, Oxford.

Carter P (1976) The effects of climatic change on settlement in eastern Lesotho during the Middle and Later Stone Age. World Archaeology 8: 197-206.

Chytrý M, Maskell LC, Pino J, Pysek P, Vila M, Font X and Smart SM (2008) Habitat invasions by alien plants: a quantitative comparison among Mediterranean, subcontinental and oceanic regions of Europe. Journal of Applied Ecology 45(2): 448-458.

Colautti RI, MacIsaac HJ (2004) A neutral terminology to define 'invasive' species. Diversity and Distributions 10: $135-141$.

Cowling RM (1983) Phytochorology and vegetation history in the south-eastern Cape, South Africa. Journal of Biogeography 10(5): 393-419.

Cruzan MB, Templeton AR (2000) Paleoecology and coalescence: phylogeographic analysis of hypotheses from the fossil record. TREE 15(12): 491-496.

Daemane ME, Van Wyk BE, Moteetee A (2010) Checklist of ferns and seed plants of the Golden Gate Highlands National Park, South Africa. Bothalia 40(2): 205-218.

Deschamps CL (2006) A comparison of the biogeographical and geomorphological characteristics of gullied and non-gullied valley head mires in eastern Lesotho. Dissertation, University of the Witwatersrand.

Dietl GP, Kidwell SM, Brenner M, Burney DA, Flessa KW, Jackson ST, Koch PL (2015) Conservation paleobiology: Leveraging knowledge of the past to inform conservation and restoration. Annual Review of Earth and Planetary Science 43: 79-103.

Du Preez PJ, Brown LR (2011) Impact of domestic animals on ecosystem integrity of Lesotho high altitude peatlands. In: Grillo O, Venora G (eds) Ecosystems biodiversity. Intech, Rijeka, pp 249-270.

Esterhuysen, A. and Mitchell, P. (1996). Palaeoenvironmental and archaeological implications of charcoal assemblages from Holocene sites in western Lesotho, Southern Africa. Palaeoecology of Africa, 24: 203 232.

Faegri K, Iversen J, Krzywinski K (1989) Textbook of Pollen Analysis. The Blackburn Press, New Jersey.

Fitchett JM, Grab SW, Bamford MK, Mackay AW (2016). A multiproxy analysis of late Quaternary Palaeoenvironments, Sekhokong Range, Eastern Lesotho. Journal of Quaternary Science, In Press.

Froyd CA, Willis KJ (2008) Emerging issues in biodiversity and conservation management: the need for a palaeoecological perspective. Quaternary Science Reviews 27: 1723-1732.

Gillson L, Ekblom A, Willis KJ, Froyd C (2008) Holocene palaeo-invasions: the link between pattern, process and scale in invasion ecology. Landscape Ecology 23: 757-769.

Grab S, Nüsser M (2001) Towards an integrated research approach for the Drakensberg and Lesotho mountain environments: A case study from the Sani Plateau region. South African Geographical Journal 83: 64-68.

Grab SW, Deschamps CL (2004) Geomorphological and Geoecological Controls and Processes Following Gully Development in Alpine Mires, Lesotho. Artic, Antarctic and Alpine Research 36(1): 49-58. 
Grab S, Scott L, Rossouw L, Meyer S (2005) Holocene palaeoenvironments inferred from a sedimentary sequence in the Tsoaing River Basin, western Lesotho. CATENA 61: 49-62.

Grab SW, Linde JH (2014) Mapping exposure to snow in a developing African context: implications for human and livestock vulnerability in Lesotho. Natural Hazards 71: 1537-1560.

Grab SW (2010) Alpine turf exfoliation pans in Lesotho, southern Africa: Climate-process-morphological linkages. Geomorphology 114: 261-275.

Grundling PL, Linström A, Fokkema W, Grootjans AP (2015) Mires in the Maluti Mountains of Lesotho. Mires and Peat 15(9): 1-11.

Hill TR (1992) Contemporary pollen spectra from the Natal Drakensberg and their relation to associated vegetation communities. PhD Thesis, Rhodes University, Grahamstown.

Jacot Guillarmod (1971) Flora of Lesotho (Basutoland). Verlag Von J. Cramer: Lehre. pp. 30-66, 271.

Joubert L (2009) Invaded, The biological invasion of South Africa. Wits University Press, Johannesburg.

Juggins S (2007) C2, Software for ecological and palaeoecological data analysis and visualisation, User guide Version 1.5. www.staff.ncl.ac.uk/stephen.juggins/software/code/C2.pdf. Accessed on 11 July 2014

Killick DJB (1963) An account of the plant ecology of the Cathedral Peak area of the Natal Drakensberg. Memoirs of the Botanical Survey of South Africa, Pretoria.

Killick DJB (1978) Notes on the vegetation of the Sani Pass area of the southern Drakensberg. Bothalia 12(3): 537-542.

Killick DJB (1990) A Field Guide: The Flora of the Natal Drakensberg. Jonathan Ball and Ad. Donker Publishers, Johannesburg.

Kopij G (2015) Avian assemblages in Afro-mountain and Alti-mountain grasslands in the endemic Maloti/Drakensberg region of Lesotho. Zoology and Ecology. doi: 10.1080/21658005.2015.1095854.

Letšela LMS (2008) A participatory sustainability assessment framework for biodiversity conservation in rural areas. PhD Thesis, University of the Free State: Bloemfontein.

Mackay AW, Bezrukova EV, Boyle JF, Holmes JA, Panizzo VN, Piotrowska N, Shchetnikov A, Shilland EM, Tarasov P, White D (2013) Multiproxy evidence for abrupt climate change impacts on terrestrial and freshwater ecosystems in the Ol'khon region of Lake Baikal, central Asia. Quaternary International 290291: 46-56.

Marake M, Mokuku C, Majoro M, Mokkitimi N (1998) Global change and subsistence rangelands in southern Africa: Resource availability, access and use in relation to rural livelihoods and welfare. National University of Lesotho, Maseru.

Marker ME (1994) Sedimentary sequences at Sani Top, Lesotho highlands, southern Africa. The Holocene 4(4): 406-412.

Martin MD, Zimmer EA, Olsen MT, Foote AD, Gilbert MTP, Brush G (2014) Herbarium specimens reveal a historical shift in phylogeographic structure of common ragweed during native range disturbance. Molecular Ecology 23: 1701-1716.

Mayer C, Soka G, Picker M (2006) The importance of monkey beetle (Scarabaeidae: Hopliini) pollination for Aizoaceae and Asteraceae in grazed and ungrazed areas at Paulshoek, Succulent Karoo, South Africa. Journal of Insect Conservation 10: 323-333. 
Mills SC, Grab SW, Carr SJ (2009) Late Quaternary moraines along the Sekhokong Range, eastern Lesotho: Contrasting the geomorphic history of north- and south-facing slopes. Geografiska Annaler 91(2): 121140.

Mitchell PJ (1995) Revisiting the Robberg: New results and a revision of old ideas at Sehonghong Rock Shelter, Lesotho. South African Archaeological Bulletin 50(161): 28-38.

Mitchell PJ (1996) The late Quaternary of the Lesotho Highlands, southern Africa: Preliminary results and future potential of ongoing research at Sehonghong shelter. Quaternary International 33: 35-43.

Mokotjomela T, Schwaibold U, Pillay N (2009) Does the ice rat Otomys sloggetti robertsi contribute to habitat change in Lesotho? Acta Oecologica 35: 437-443.

Morris CD, Boleme S, Tainton NM (1989) Report on investigations into the fire and grazing regimes and the conservation needs of the eastern alpine catchments of Lesotho. Drakensberg/Maluti Mountain catchment Conservation Programme, Fire and Grazing Project, Pietermaritzburg.

Morris CD, Taintoi NM, Boleme S (1993) Classification of the eastern alpine vegetation of Lesotho. African Journal of Range and Forage Science 10(1): 57-53.

Mucina L, Hoare DB, Lötter MC, du Preez J, Rutherford MC, Scott-Shaw R, Bredenkamp GJ, Powrie LW, Scott L, Camp KGT, Cilliers SS, Bezuidenhout H, Mostert TH, Siebert SJ, Winter PJD, Burrows JE, Dobson L, Ward RA, Stalmans M, Oliver EGH, Sibert F, Schmidt E, Kobisi K and Kose L (2006) Grassland Biome. In: Mucina L, Rutherford MC (Eds) The vegetation of South Africa, Lesotho and Swaziland. South African National Biodiversity Institute, Cape Town.

Nel W, Sumner PD (2005) First rainfall data from the KZN Drakensberg escarpment edge (2002 and 2003 ). Water SA 31(3): 399-402.

Nel W, Sumner P (2008) Rainfall and temperature attributes on the Lesotho-Drakensberg escarpment edge, Southern Africa. Geografiska Annaler 90(1): 97-108.

Nüsser M, Grab S (2002) Land degradation and soil erosion in the eastern Highlands of Lesotho, Southern Africa. Die Erde 133: 291-311.

Ormerod SJ, Pienkowski MW, Watkinson AR (1999) Communicating the value of ecology. Journal of Applied Ecology 36: 847-855.

Osman AKE (2011) Pollen Morphology of Tribes Gnaphalieae, Helenieae, Plucheeae and Senecioneae (Subfamily Asteroideae) of Compositae from Egypt. American Journal of Plant Sciences 2: 120-133.

Parker AG, Lee Thorp J, Mitchell PJ (2011) Late Holocene Neoglacial conditions from the Lesotho highlands, southern Africa: phytolith and stable carbon isotope evidence from the archaeological site of Likoaeng. Proceedings of the Geologists' Association 122: 201-211.

Petit RJ, Hu FS, Dick CW (2008) Forests of the past: a window to future changes. Science 320: 1450-1452.

Pooley E (1998) A Field Guide to Wild Flowers: Kwazulu-Natal and the Eastern Region. Natal Flora Publication Trust, Durban.

Preston CD, Pearman DA, Hall AR (2004) Archaeophytes in Britain. Botanical Journal of the Linnean Society 145: 257-294.

Quinlan T, Morris CD (1994) Implications of changes to the transhumance system for conservation of the mountain catchments in eastern Lesotho. African Journal of Range and Forage Science 11(3): 76-81. 
Roberts P, Lee-Thorp JA, Mitchell PJ, Arthur C (2013) Stable carbon isotopic evidence for climate change across the late Pleistocene to early Holocene from Lesotho, southern Africa. Journal of Quaternary Science 28(4): 360-369.

Robinson K (2014) Assessment of the effects of fire and associated grazing on the recovery of Merxmuellera drakensbergensis in the Sani Pass region, Lesotho. PhD Thesis, University of the Witwatersrand, Johannesburg.

Rouget M, Richardson DM, Nel JL, Le Maitre DC, Egoh B, Mgidi T (2004) Mapping the potential ranges of major plant invaders in South Africa, Lesotho and Swaziland using climatic suitability. Diversity and Distributions 10: 475-484.

Rutherford MC, Powrie LW, Husted LB (2012) Plant diversity consequences of a herbivore-driven biome switch from Grassland to Nama-Karoo shrub steppe in South Africa. Applied Vegetation Science 15: 1425 .

Schalke HJWG (1973) The Upper Quaternary of the Cape Flats area (Cape Province, South Africa). Scripta Geologica 15: 1-48.

Schwabe CA, Whyte CR (1993) An Investigation into the Distribution of Wetlands and Grasslands and their Carrying Capacities within the Mokhotlong district of Lesotho. Department of Foreign Affairs, Pietermaritzburg.

Schwabe C (1995) Alpine mires of the eastern highlands of Lesotho. In: Cowan G (ed). Wetlands in Southern Africa. Department of Environmental Affairs and Tourism, Pretoria.

Scott L (1982) Late Quaternary fossil pollen grains from the Transvaal, South Africa. Review of Palaeobotany and Palynology 36: 241-278.

Scott L, Neumann FH, Brook GA, Bousan CB, Norström E, Metwally AA (2012) Terrestrial fossil-pollen evidence of climate change during the last 26 thousand years in Southern Africa. Quaternary Science Reviews 32: 100-118.

Seddon AW, Mackay AW, Baker AG, Birks HJB, Breman E, Buck CE, Ellis EC, Froyd CA, Gill JL, Gillson L, Johnson EA, Jones VJ, Juggins S, Macias-Fauria M, Mills K, Morris JL, Nogués-Bravo D, Punyasena SW, Roland TP, Tanentzap AJ, Willis KJ, Aberhan M, Van Asperen EN, Austin WEN, Battarbee RW, Bhagwat S, Belanger CL, Bennett KD, Birks HH, Bronk Ramsay C, Brooks SJ, De Bruyn M, Butler PG, Chambers FM, Clarke SJ, Davies AL, Dearing JA, Ezard THG, Feurden A Flower RJ, Gell P, Hausmann S, Hogan, Hopkins MJ, Jeffers ES, Korhola AA, Marchant R, Kiefer T, Lamentowicz M, Larocque-Tobler I, LópezMerino L, Liow LH, McGowan S, Miller JH, Montoya E, Morton O, Nogué S, Onoufriou C, Bousch LP, Rodriguez-Sanchez F, Rose NL, Sayer, CD, Shaw HE, Payne R, Simpson G, Sohar K, Whitehouse NJ, Williams JW, Witkowski A (2014) Looking forward through the past: identification of 50 priority research questions in palaeoecology. Journal of Ecology 102: 256-267.

Scott L (2014) Personal Communication.

Showers KB (2005) Imperial gullies: Soil erosion and conservation in Lesotho. Ohio University Press, Athens, pp 115-176.

Squires VR, Trollope WSW (1979) Allelopathy in the Karroo shrub Chrysocoma tenufolia. South African Journal of Science 75: 88-89.

Stewart B, Dewar G, Morley M, Inglis R, Wheeler M, Jacobs Z, Roberts R (2012) Afromontane foragers of the Late Pleistocene: Site formation, chronology and occupational pulsing at Melikane Rockshelter, Lesotho. Quaternary International 270: 40-60. 
Van Der Knaap WO, Van Leeuwen JFN, Froyd CA, Willis KJ (2012) Detecting the provenance of Galapagos non-native pollen: The role of humans and air currents as transport mechanisms. The Holocene 22(12): 1373-1383.

Van Leuuwen JFN, Schäfer H, Van Der Knaap WO, Rittenour T, Björck S, Ammann B (2005) Native or introduced? Fossil pollen and spores may say. An example from the Azores Islands. NEOBIOTA 6: 27-34.

Van Leeuwen JFN, Froyd CA, Van Der Knaap WO, Coffey EE, Tye A, Willis KJ (2008) Fossil pollen as a guide to conservation in the Galapagos. Science 322: 1205-1206.

Van Zinderen Bakker EM (1955) A Preliminary Survey of the Peat Bogs of the Alpine Belt of Northern Basotholand. Acta Geographica 14: 413-422

Van Zinderen Bakker EM (1981) The high mountains of Lesotho - a botanical paradise. Veld and Flora 67: 106-108.

Van Zinderen Bakker EM, Werger MJA (1974) Environment, vegetation and phytogeography of the highaltitude bogs of Lesotho. Vegetatio 29: 37-49.

Venables WN, Smith DM (2015) An Introduction to R, Notes on R: A Programming Environment for Data Analysis and Graphics Version 3.1 .3 (2015-03-09). www.cran.r-project.org/manuals/r-release/R-intro.pdf Accessed on 14 December 2014.

Vetter S, Goqana WM, Bond WJ, Trollope WW (2006) Effects of land tenure, geology and topography on vegetation and soils of two grassland types in South Africa. African Journal of Range and Forest Science 23(1): 13-27.

Webb DA (1985) What are the criteria for presuming native status? Watsonia 15: 231-236.

Willis KJ, Gillson L, Brncic TM, Figueroa-Rangel BL (2005) Providing baselines for biodiversity measurement. Trends in Ecology and Evolution 20(3): 107-108.

Willis KJ, Birks HJB (2006) What is natural? The need for a long-term perspective in biodiversity conservation. Science 314: 1261-1267.

Willis KJ, Araújo MB, Bennett KD, Figueroa-Rangel C, Froyd A, Myers N (2007) How can a knowledge of the past help to conserve the future? Biodiversity conservation and the relevance of long-term ecological studies. Philosophical Transactions: Biological Sciences 362(1478): 175-186.

Wilmshurst JM, Moar NT, Wood JR, Bellingham PJ, Findlater AM, Robinson JJ, Stone C (2013) Use of pollen and ancient DNA as conservation baselines for offshore islands in New Zealand. Conservation Biology 28(1): 202-212.

Wilmshurst JM, McGlone MS, Turney CSM (2015) Long-term ecology resolves the timing, region of origin and process of establishment for a disputed alien tree. AoB Plants. doi: 10.1093/aobpla/plv104.

Figure captions

Figure 1: Photograph of a) Chrysocoma ciliata bush (after Botha and Venter, 2002) and b) proliferation of Chrysocoma ciliata surrounding an abandoned cattle station in eastern Lesotho.

Figure 2: Map of Lesotho indicating the position of the study site at Sani Top.

Figure 3: BACON output for the Sani Valley profile, providing interpolated ages for depths

Figure 4: Photographs of the Chrysocoma sp. pollen grains from the Sani Top core and comparative material. AC, Sani top pollen (A: brightfield standard contrast, B: brightfield high contrast, C: Nomarski DIC). D-J Comparative material from the pollen reference collection of the University of the Free State (Photograph credit: 
L Scott, published with his permission): D-F Chrysocoma ciliata, G - Chrysocoma polygalyfolia, H Helychrysum degeanum, I-J. Helychrysum zeyheri.

Figure 5: Stratigraphic diagram of the pollen results for the Sani Top, with total pollen counts for Chrysocoma ciliata indicated on the far right.

Figure 6: PCA biplot for pollen results from the Sani Valley profile.

Table captions:

Table 1: References to Chrysocoma ciliata in the literature.

Table 2: Contemporary vegetation in the Sani vicinity of Sani Top

Table 3: AMS radiocarbon dates acquired for the Sani Valley profile.

Table 4: Frequency of occurrence of pollen identified from the Sani Valley sequence.

Table 1: References to Chrysocoma ciliata in the literature

\begin{tabular}{|c|c|c|c|c|c|}
\hline Publication & Invasive & $\begin{array}{l}\text { Karroid } \\
\text { Invasive }\end{array}$ & $\begin{array}{l}\text { Anthropogenically } \\
\text { introduced }\end{array}$ & $\begin{array}{l}\text { Common in overgrazed } \\
\text { areas }\end{array}$ & Native \\
\hline Van Zinderen Bakker, 1955 & $\checkmark$ & & & & \\
\hline Beverly, 1980 & $\checkmark$ & & $\checkmark$ & $\checkmark$ & \\
\hline Chakela, 1981 & & $\checkmark$ & $\checkmark$ & $\checkmark$ & \\
\hline Killick, 1987 & & $\checkmark$ & & & \\
\hline Killick, 1990 & & $\checkmark$ & & $\checkmark$ & \\
\hline Quinlan and Morris, 1994 & & $\checkmark$ & & $\checkmark$ & \\
\hline Quinlan, 1995 & & $\checkmark$ & & & \\
\hline Esterhuysen and Mitchell, 1996 & & & & $\checkmark$ & \\
\hline Grab and Nüsser, 2001 & & & & $\checkmark$ & \\
\hline \multicolumn{6}{|l|}{ Nüsser, 2002 (translated) } \\
\hline Nüsser and Grab, 2002 & & $\checkmark$ & & $\checkmark$ & \\
\hline Morris et al., 2003 & & $\checkmark$ & & & \\
\hline Carbutt and Edwards, 2004 & & & & & $\checkmark$ \\
\hline Grab and Deschamps, 2004 & $\checkmark$ & $\checkmark$ & & $\checkmark$ & \\
\hline Grab et al., 2005 & & $\checkmark$ & & & \\
\hline Deschamps, 2006 & $\checkmark$ & $\checkmark$ & & $\checkmark$ & \\
\hline Vetter et al., 2006 & & $\checkmark$ & & $\checkmark$ & \\
\hline Letšela, 2008 & & & & & $\checkmark$ \\
\hline Du Preez and Brown, 2011 & & & & $\checkmark$ & \\
\hline FAO, 2011 & $\checkmark$ & & & $\checkmark$ & \\
\hline
\end{tabular}




\begin{tabular}{|c|c|c|c|}
\hline Carbutt, 2012 & & & $\checkmark$ \\
\hline Grab, 2012 & $\checkmark$ & & \\
\hline Robinson, 2014 & $\checkmark$ & $\checkmark$ & \\
\hline Brand et al., 2015 & & $\checkmark$ & \\
\hline Grundling et al., 2015 & $\checkmark$ & $\checkmark$ & \\
\hline Kopij, 2015 & $\checkmark$ & $\checkmark$ & \\
\hline
\end{tabular}

Table 2: Contemporary vegetation in the Sani vicinity of Sani Top

\begin{tabular}{lll}
\hline Species & Family & Classification \\
\hline Trifolium burchellianum & Fabaceae & Dryland \\
Selago flanaganii & Scrophulariaceae & \\
Helichrysum subglomeratum & Asteraceae & \\
Helichrysum flanaganii & Asteraceae & \\
Geranium multisectum & Geraniaceae & \\
Anthospermum basutocum & Rubiaceae & \\
Helichrysum aureum var. aureum & Asteraceae & \\
Helicchrysum sessillodes & Asteraceae & \\
Erica sp. & Ericaceae & \\
Erica dominans & Ericaceae & \\
Centella asiatica & Apiaceae & \\
Alchemilla woodii & Rosaceae & \\
Senecio inaequadens & Asteraceae & \\
Helichrysum milifordiae & Asteraceae & \\
Crassula sp. & Crassulaceae &
\end{tabular}




\begin{tabular}{|c|c|c|}
\hline Delosperma sp. & Aizoaceae & Shrubs \\
\hline Helichrysum trilineatum & Asteraceae & \\
\hline Chrysocoma ciliata & Asteraceae & \\
\hline Eumorphia sericea & Anthemideae & \\
\hline Polygala amatymbica & Polygalaceae & \\
\hline Merxmuellera drakensbergensis & Poaceae & Grass \\
\hline Agrostis subulifolia & Poaceae & \\
\hline Haplocarpha nervosa & Asteraceae & Wetland \\
\hline Ranunculus multifidus & Ranunculaceae & \\
\hline Rhodohypoxys rubella & Hypoxidaceae & \\
\hline Saniella verna & Hypoxidaceae & \\
\hline Kniphofia caulescens & Xanthorrhoaeceae & Wetland \\
\hline Aponogeton junceus. & Aponogetonaceae & \\
\hline Wurmbea elatlor & Colchicaceae & \\
\hline Limosella major & Scrophulariaceae & \\
\hline Limosella vesiculosa & Scrophulariaceae & \\
\hline Ranunculus meyeri & Ranunculaceae & \\
\hline Sebaea filiformis & Gentianaceae & \\
\hline Lobelia \pm filiformis & Campanulaceae & \\
\hline Rhodohypoxis rubella & Hypoxidaceae & \\
\hline Cotula paludosa & Asteraceae & \\
\hline Alepidea \pm pusilla & Apiaceae & \\
\hline Oxalis obliquifolia & Oxalidaceae & \\
\hline Nostoc sp. & Nostocaceae & \\
\hline
\end{tabular}

Table 3: AMS radiocarbon dates acquired for the Sani Valley profile.

\begin{tabular}{llllll}
\hline $\begin{array}{l}\text { Laboratory } \\
\text { ID }\end{array}$ & $\begin{array}{l}{ }^{14} \mathbf{C} \text { Age }(\mathbf{y r} \\
\mathbf{B P})\end{array}$ & $\begin{array}{l}\mathbf{1 \sigma} \\
\text { Uncertainty } \\
(\mathbf{y r})\end{array}$ & $\begin{array}{l}\mathbf{2 \sigma} \text { calibrated age } \\
\text { range (BP) }\end{array}$ & $\begin{array}{l}\text { Mean } \\
\text { Depth (cm) }\end{array}$ & $\begin{array}{l}\text { Sample } \\
\text { thickness }\end{array}$ \\
\hline WITSS10 & 270 & \pm 30 & $310-270$ & 18 & $3 \mathrm{~cm}$ \\
WITSS13 & 700 & \pm 30 & $660-555$ & 38 & $3 \mathrm{~cm}$ \\
WITSS5 & 1,630 & \pm 30 & $1,535-1,375$ & 57 & $3 \mathrm{~cm}$ \\
WITSS21 & 4,020 & \pm 30 & $4,330-4,295$ & 78 & $3 \mathrm{~cm}$ \\
\hline
\end{tabular}


Table 4: Frequency of pollen occurrence identified from the Sani Valley sequence.

\begin{tabular}{lll}
\hline Pollen type (family/genera) & $\begin{array}{l}\text { \% Occurrence in } \\
\text { core }\end{array}$ & Maximum individual sample \% \\
\hline Cyperaceae & 52.9 & 78.2 \\
Asteraceae & 17.6 & 42.4 \\
Poaceae & 16.8 & 31.1 \\
Crassula spp. & 3.3 & 10.6 \\
Aizoaceae & 1.4 & 4.2 \\
Cheno-Am & 1.9 & 3.6 \\
Caryophylaceae & 1.2 & 4.7 \\
Apiaceae & 1.1 & 4.8 \\
Pentzia spp. & 0.8 & 2.0 \\
Indigofera spp. & 0.7 & 4 \\
Liliaceae & 0.5 & 1.6 \\
Olea sp. & 0.5 & 2.4 \\
Typha spp. & 0.4 & 2.8 \\
Gentianaceae & 0.4 & 2.4 \\
Vernonia spp. & 0.4 & 2.4 \\
Chrysocoma sp. & 0.2 & 1.2 \\
Acanthaceae & 0.2 & 0.8 \\
Passerina spp. & 0.2 & 1.2 \\
Malvaceae & 0.1 & 1.2 \\
Anthospermum spp. & 0.1 & 1.2 \\
Podocarpus sp. & 0.1 & 0.8 \\
Geraniaceae & 0.1 & 0.4 \\
Pinus sp. & 0.1 & 0.8 \\
Ericaceae & $<0.1$ & 0.4 \\
Widdringtonia spp. & $<0.1$ & 0.4 \\
\hline & & \\
\hline
\end{tabular}




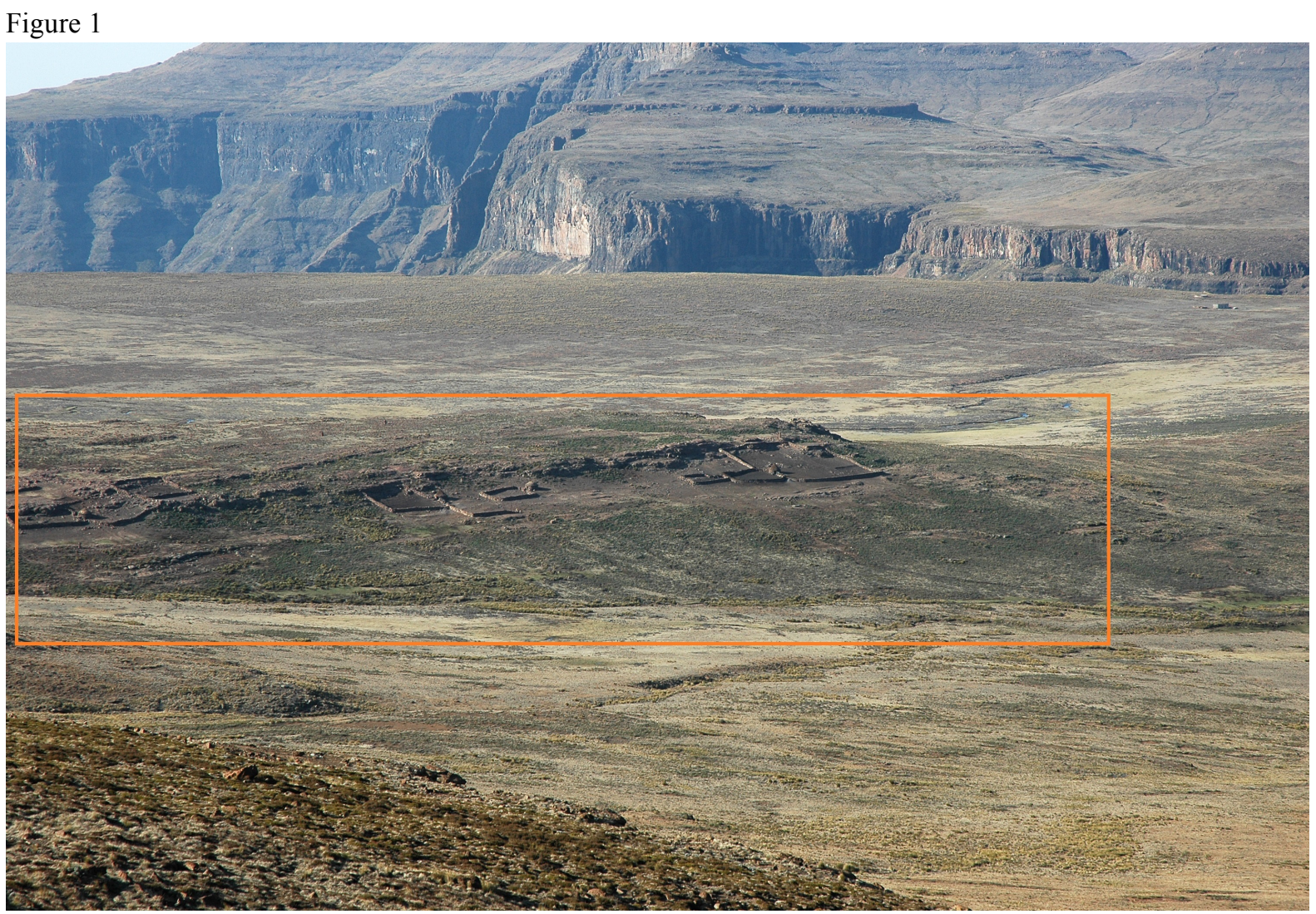


Fig 1b

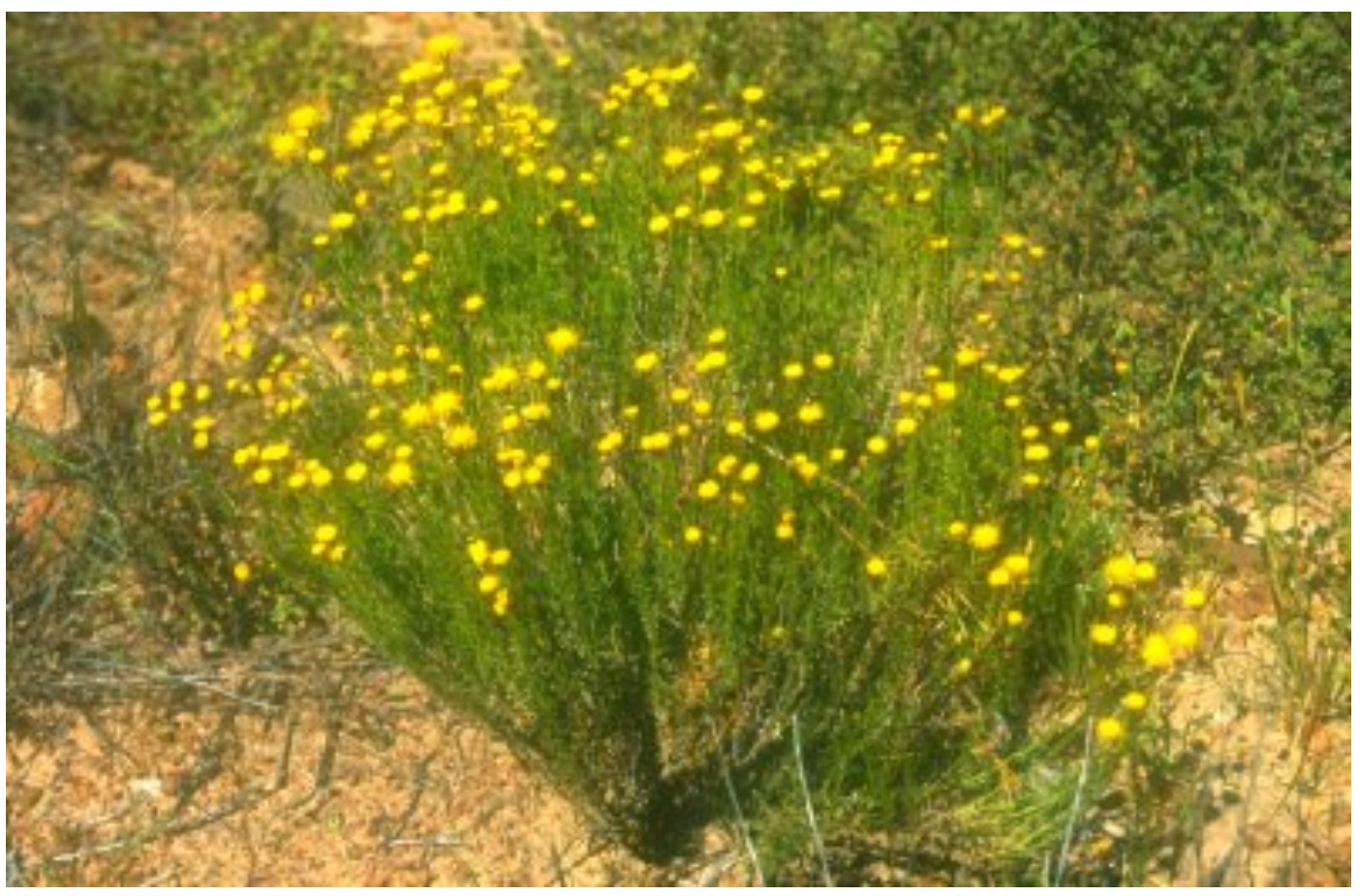


Fig 2

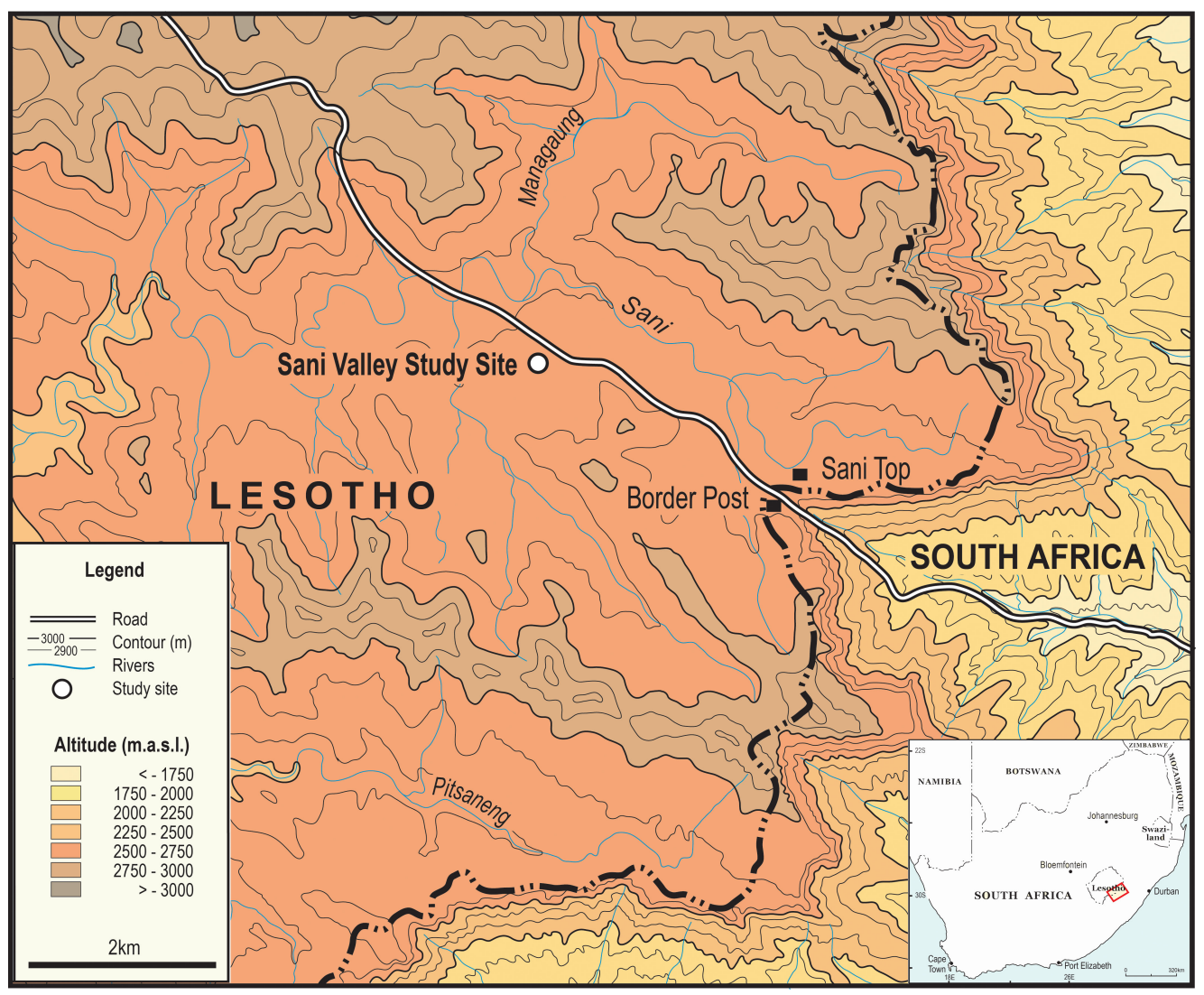


Fig 3

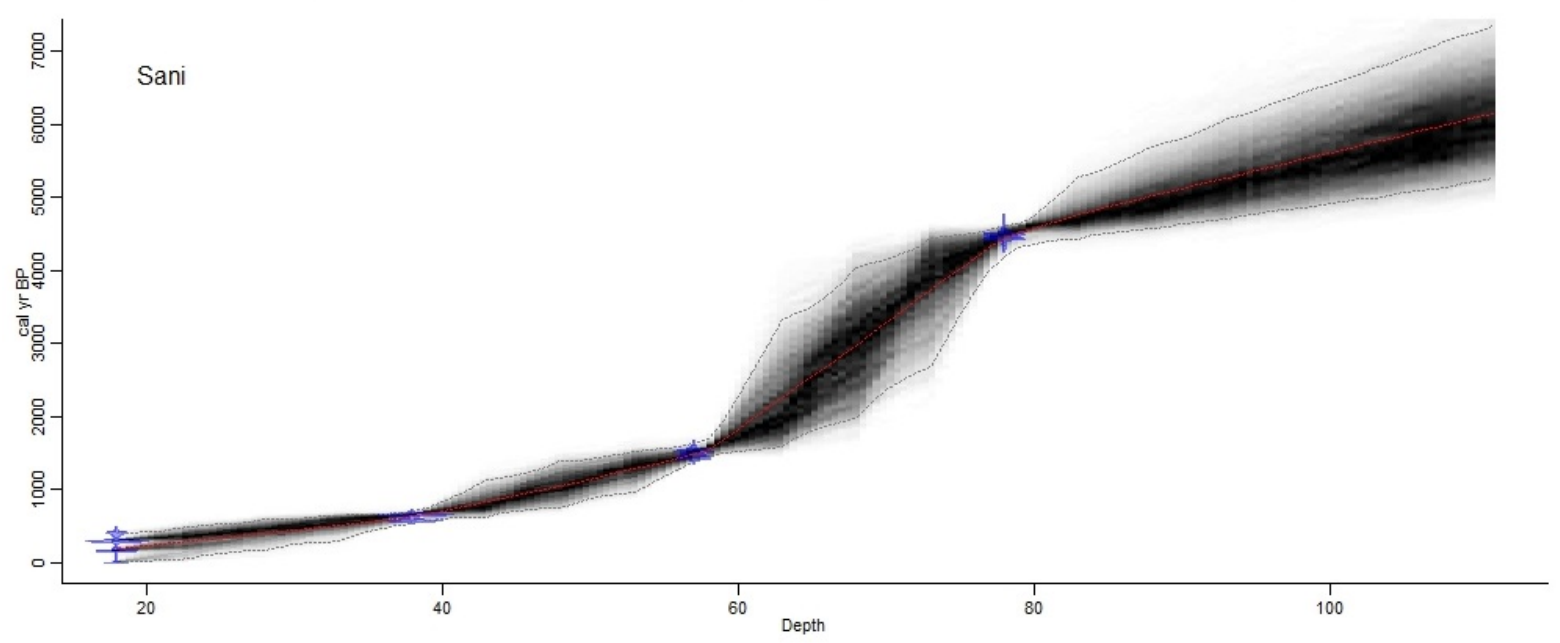


Fig 4

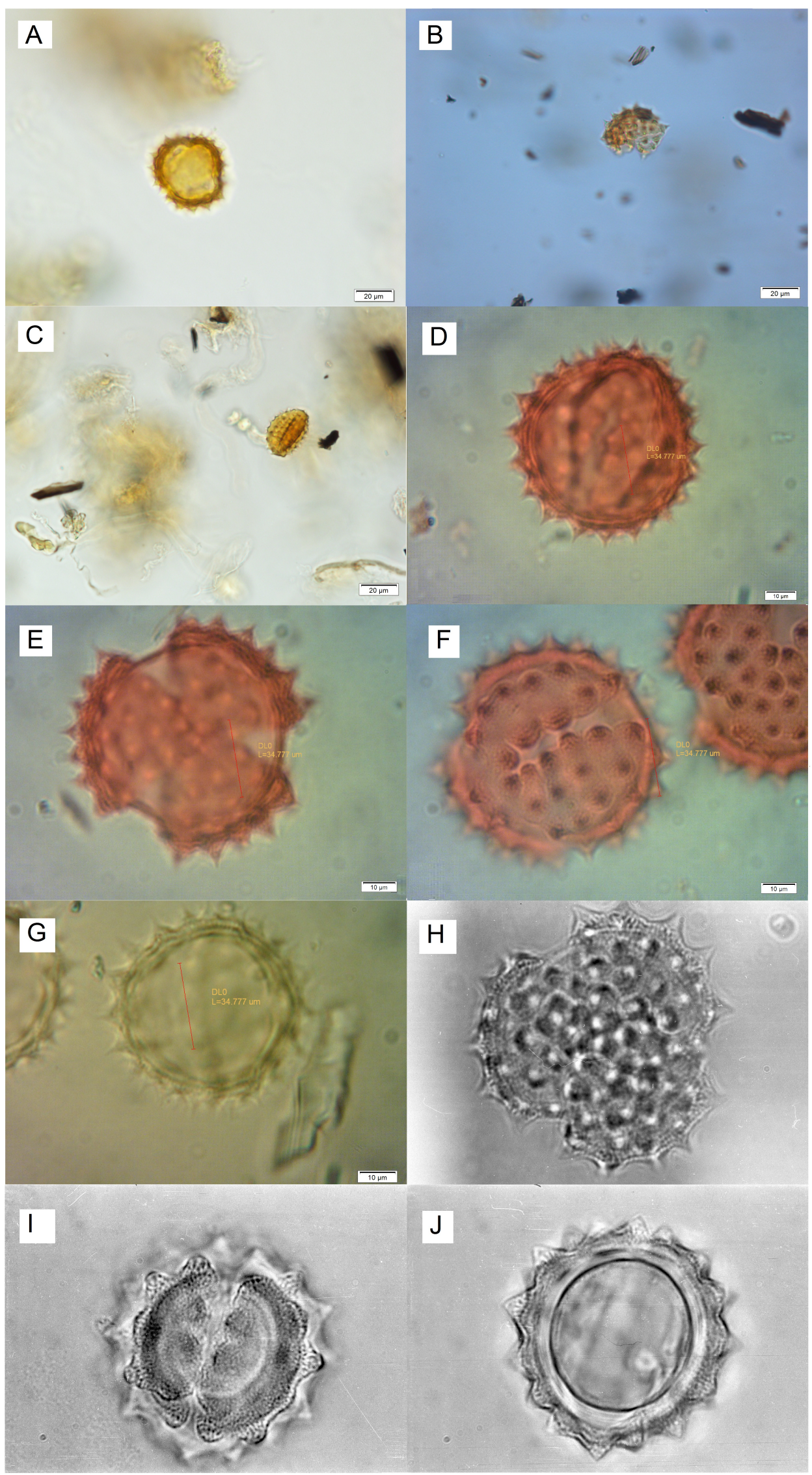


Fig 5

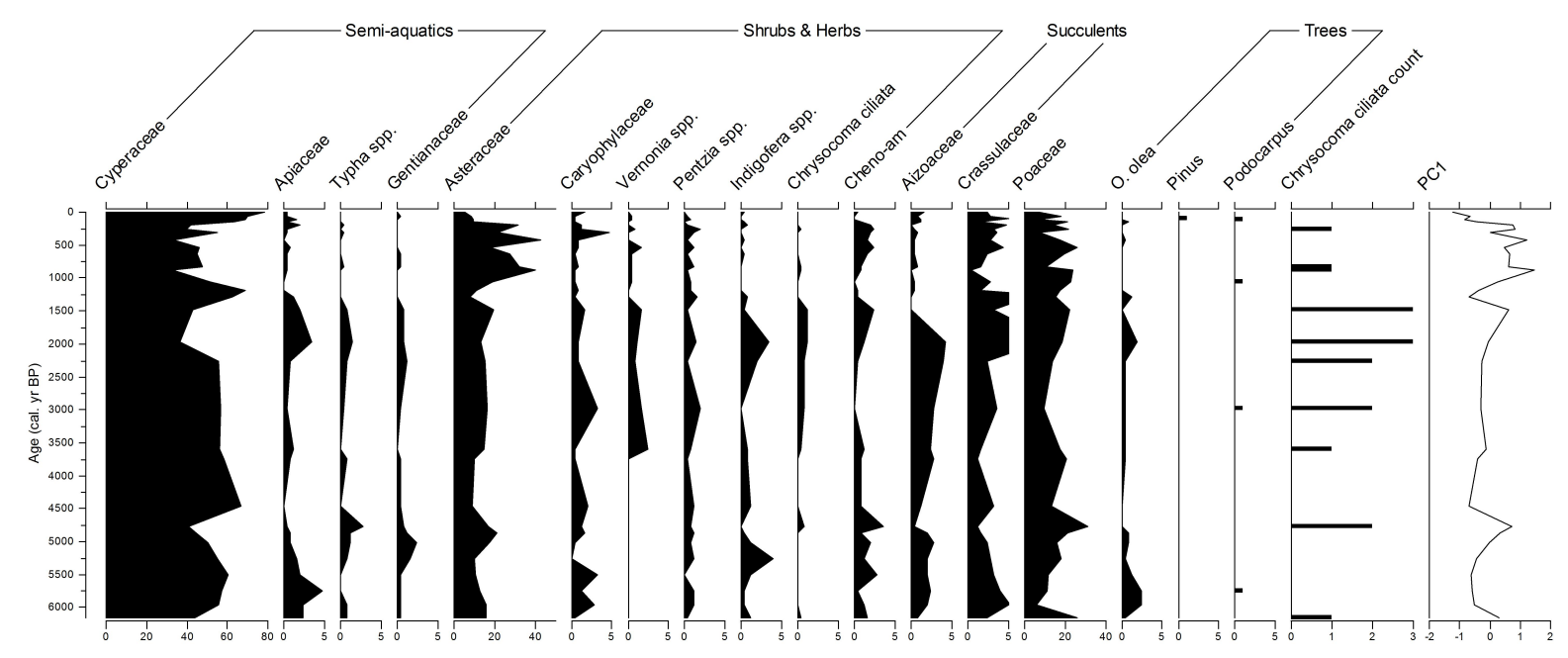


Fig 6

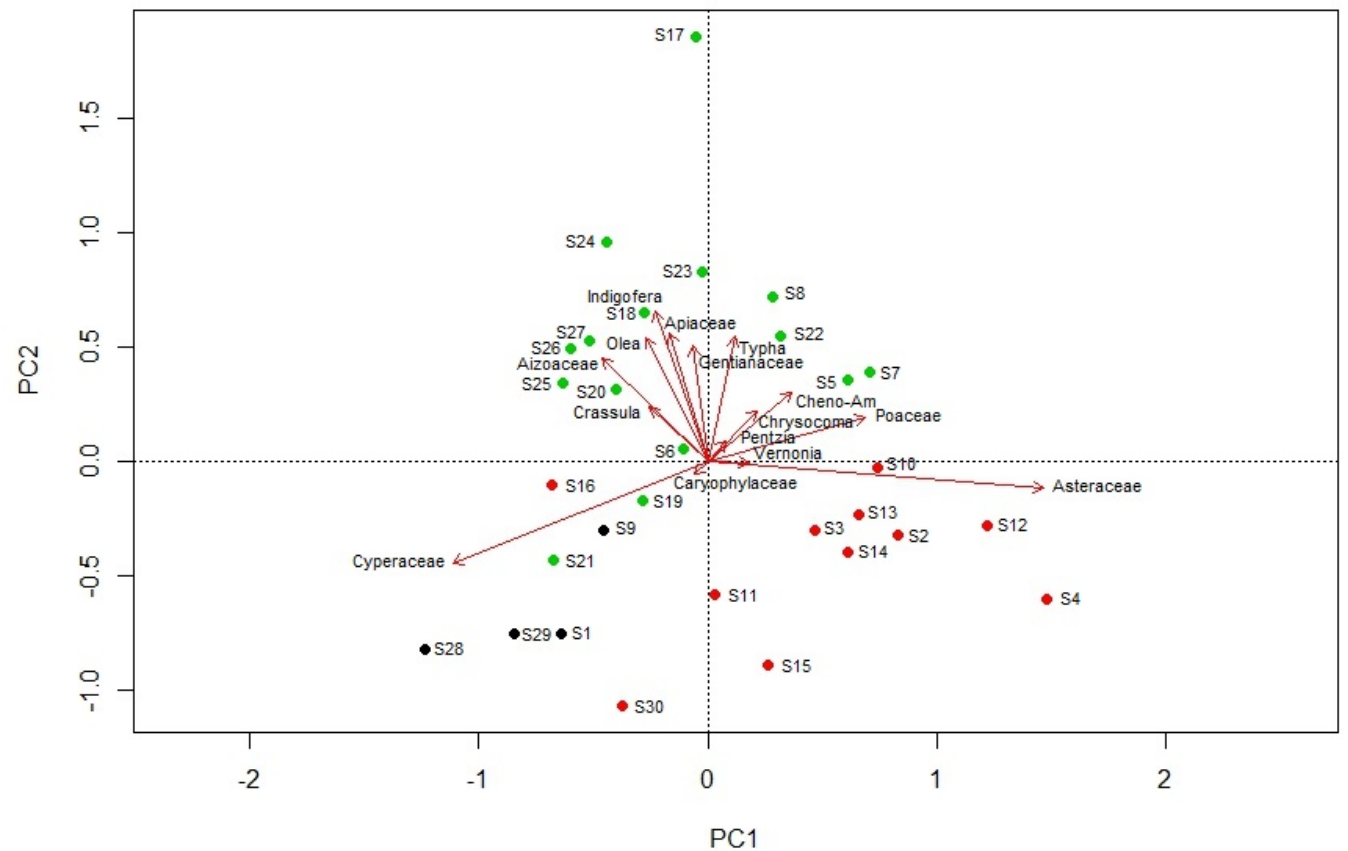

